\title{
Exercise and eating habits among urban adolescents: a cross-sectional study in Kolkata, India
}

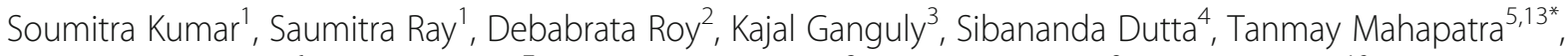
Sanchita Mahapatra ${ }^{6}$, Kinnori Gupta ${ }^{7}$, Kaushik Chakraborty ${ }^{8}$, Mrinal Kanti Das ${ }^{9}$, Santanu Guha ${ }^{10}$, Pradip K. Deb ${ }^{11}$ and Amal K. Banerjee ${ }^{12}$

\begin{abstract}
Background: Unhealthy eating and lack of exercise during adolescence culminated into earlier onset and increasing burden of atherosclerotic cardiovascular diseases (CVDs) worldwide. Among urban Indian adolescents, prevalence of these risk factors of CVD seemed to be high, but data regarding their pattern and predictors was limited. To address this dearth of information, a survey was conducted among urban adolescent school-students in Kolkata, a highly populated metro city in eastern India.

Methods: During January-June, 2014, 1755 students of 9th-grade were recruited through cluster (schools) random sampling. Informed consents from parents and assents from adolescents were collected. Information on socio-demographics, CVD-related knowledge and perception along with eating and exercise patterns were collected with an internally validated structured questionnaire. Descriptive and regression analyses were performed in SAS-9.3.2.

Results: Among 1652 participants (response rate $=94.1 \%$ ), about 44\% had poor overall knowledge about CVD, 24\% perceived themselves as overweight and 60\% considered their general health as good. Only 18\% perceived their future CVD-risk and 29\% were engaged in regular moderate-to-vigorous exercise. While 55\% skipped meals regularly, 90\% frequently consumed street-foods and 54\% demonstrated overall poor eating habits. Males were more likely to engage in moderate-to-vigorous exercise [adjusted odds ratio (AOR) $=3.40$ ( $95 \%$ confidence interval $=2.55-4.54)]$ while students of higher SES were less likely $[A O R=0.59(0.37-0.94)]$. Males and those having good CVD-related knowledge were more likely to exercise at least $1 \mathrm{~h} /$ day $[\mathrm{AOR}=7.77$ (4.61-13.07) and 2.90(1.46-5.78) respectively].

Those who perceived their future CVD-risk, skipped meals more [2.04(1.28-3.25)] while Males skipped them less $[A O R=0.62(0.42-0.93)]$. Subjects from middle class ate street-foods less frequently $[A O R=0.45(0.24-0.85)]$. Relatively older students and those belonging to higher SES were less likely to demonstrate good eating habits $[A O R=0.70(0$. 56-0.89) and 0.23(0.11-0.47) respectively]. A large knowledge-practice gap was evident as students with good CVD-related knowledge were less likely to have good eating habits [AOR $=0.55(0.32-0.94)]$.

(Continued on next page)
\end{abstract}

\footnotetext{
* Correspondence: drtanmaymahapatra@yahoo.com

${ }^{5}$ Fielding School of Public Health, University of California - Los Angeles, Los

Angeles, CA 90095, USA

${ }^{13}$ Mission Arogya Health and Information Technology Research Foundation,

8 Dr. Ashutosh Sastri Road, Kolkata, West Bengal 700010, India

Full list of author information is available at the end of the article
}

(c) The Author(s). 2017 Open Access This article is distributed under the terms of the Creative Commons Attribution 4.0 International License (http://creativecommons.org/licenses/by/4.0/, which permits unrestricted use, distribution, and reproduction in any medium, provided you give appropriate credit to the original author(s) and the source, provide a link to the Creative Commons license, and indicate if changes were made. The Creative Commons Public Domain Dedication waiver (http://creativecommons.org/publicdomain/zero/1.0/) applies to the data made available in this article, unless otherwise stated. 
(Continued from previous page)

Conclusions: CVD-related knowledge as well as eating and exercise habits were quite poor among adolescent schoolstudents of Kolkata. Additionally, there was a large knowledge-practice gap. Multi-component educational interventions targeting behavioral betterment seemed necessary for these adolescents to improve their CVD-related knowledge, along with appropriate translation of knowledge into exercise and eating practices to minimize future risk of CVDs.

Keywords: Eating habits, Exercise, Adolescent, Urban, Kolkata

\section{Background}

Exponential increase in the global burden of noncommunicable diseases (NCDs) marked the beginning of the twenty-first century. Population aging, improved survival opportunities and rapid rise in obesogenic environment were the potential contributors. Cardiovascular diseases (CVDs), globally the most common cause of NCD-related deaths [1], attributed for about 17.5 million deaths in 2012 [2]. About $75 \%$ of these CVD deaths were from low-andmiddle-income countries [2].

Compared to Western populations, in South Asian countries, higher prevalence and a decade earlier onset of CVDs were experienced owing to unique genetic predisposition and earlier exposure to risk factors $[3,4]$. Ischemic heart disease (IHD) continued to be the most common cause of mortality among working adults (15-69 years) in Asian countries [5]. Among all major ethnic groups in South Asia, Indians were found to be at highest risk for CVDs, especially premature coronary heart diseases $[4,6,7]$. Interplay of unhealthy diet (added high sugar and refined grains), vitamin-D deficiency, tobacco use and physical inactivity contributed to this elevated risk for CVDs among Indians, especially in urban areas. In addition, the rising epidemic of type- 2 diabetes mellitus further increased the vulnerability of Asian Indians to IHD $[8,9]$.

Thus a clear understanding of the potential predictors of CVDs appeared to be crucial for appropriate designing and timely (before the initiation of atherosclerosis) implementation of preventive interventions to control the rising tide of CVDs [10, 11]. Clustering of cardiovascular risk factors and initiation (appearance of fatty streaks) of atherosclerotic CVDs start in the second decade of life and get influenced by genetic and environmental exposures (serum lipid concentrations/smoking/obesity/hyperglycemia) during lifetime [12-14]. Furthermore, sustained high blood pressure was observed to accelerate atherosclerosis in the third decade of life [12, 15-17]. Rapid urbanization probably exposed individuals to these life-threatening yet modifiable/reversible risk factors quite early in life [11, 18]. For example, worldwide, among school-aged children, 10\% were overweight $[19]$ and $>3 \%$ children and adolescents were hypertensive [20]. In addition, inadequate knowledge regarding CVDs coupled with low-risk perceptions among adolescents further heightened their susceptibility for CVDs [21].
Alike Western countries, South Asian children were also at high risk of developing CVDs in their future life, mostly because of deleterious life-styles and behaviors [22]. Among urban Indians, exposure to multiple risk factors of CVD was evidenced during adolescence and dramatically increased by 30-39 years of age [23]. Among Indian school children, high prevalence of overweight $(14.4 \%)$, obesity $(2.8 \%)$, sustained high blood pressure [24, 25], coupled with maternal and fetal under-nutrition were suspected to increase the future risk of CVDs [13].

Quality data regarding exercise and eating habits along with related knowledge, perceptions and consequent practices related to the risk of future CVDs in this target population were limited in India. The aim of this study was thus to assess the CVD-related knowledge, health perceptions (especially about future CVD-risk), eating habits, exercise patterns and their interplay among urban adolescent students in Kolkata, a metropolitan city in eastern India.

\section{Methods}

Design

A cross-sectional study was conducted among adolescent school students of Kolkata between January and December 2014. Students of 9th grade (aged 14-16 years) were selected as the study population group, as a proxy for the adolescent school-children of metropolitan Kolkata.

\section{Sample size and sampling strategy}

Cluster random sampling strategy was used for the study using schools as the clusters. The rate of homogeneity (roh) between clusters was assumed to be equal to the intra-cluster correlations owing to the single-stage sampling method $[26,27]$. Considering the possibility that characteristics relevant to this study (socio-demographics, CVD related knowledge and perception, exercise patterns and eating habits) were likely to be more correlated among the students within the same schools, we empirically assumed roh $=0.2$, a relatively higher value, as per standard recommendations [26, 28].

Based on the information collected from all the governing bodies of the operational educational boards in Kolkata, the average number of students studying in the 9th grade per school was found to be approximately 
75. Hence assuming the average cluster size (b) to be 75 , using the formula: $\mathrm{D}=1+(\mathrm{b}-1)$ roh, the design effect, $\mathrm{D}$ was calculated to be $=13.8$ [26-28].

Appropriate population parameter was not available from the study area. Hence following the most conservative approach to ensure the recruitment of adequate subjects for determining the estimates with 95\% confidence interval having a standard error of 0.05 (s), we empirically used 0.5 as the expected proportion (p).

Using this design effect and other assumptions as mentioned before, according to the appropriate formula [required sample size, $n=p(1-p) D / s^{2}$ ], 1580 students were required to be recruited from 21 schools [no. of clusters (schools), $\left.c=p(1-p) D / s^{2} b=21.067\right]$. Assuming $10 \%$ non-response we planned to invite 1755 students and their guardians to participate in our study.

\section{Selection of schools}

Initially, an exhaustive list of 426 secondary-level schools in Kolkata metropolitan area was prepared. The schools were stratified according to the socio-economic strata (higher/middle/low) they generally catered as well as the type of students enrolled (co-educational/boys only/girls only). Ensuring the recruitment of at least two schools per strata, using stratified random sampling based on school types and socio-economic status (SES) with probability proportion to size, 21 schools were selected from the list. With administrative support from the Department of School Education, Government of West Bengal, all these schools were invited. Time, date and venue of data collection were finalized ensuring maximum attendance, after completion of necessary formalities in 19 schools who agreed to participate. All students of the selected schools and their parents (preferably mothers) were invited through written letters to participate in the study.

\section{Study population}

All 9th grade students present on the day of data collection in the selected schools, were recruited for the study if accompanied by one of their guardians (preferably mothers), agreed to participate by providing written voluntary assents and their accompanying guardians or their legally authorized representative provided written informed consents. Students with any medical or psychiatric illnesses preventing normal communications were excluded from the study.

\section{Data collection and measures}

Information was collected through a self-administered, structured questionnaire, which was pre-tested for internal consistency and internally validated [29] in a sample of 160 students (approximately 10\% of the total sample size) of same grade, recruited from two randomly selected schools of the study area. Collected socio-demographic information included: age, gender and SES of the students (based on family income).

CVD-related knowledge was assessed in the following five domains: CVDs in general (heard of heart attacks/ causes/symptoms), high blood pressure (cause/symptoms), risk factors for CVDs (smoking/obesity/low cholesterol/ raised sugar/stress/high fiber diet/positive family history/ physical activity), prevention of CVDs and healthy nutritional habits. Based on standard textbooks and guidelines, correct and incorrect responses to individual knowledgeassessment questions were scored as 1 and 0 respectively. To estimate domain-specific and overall knowledge related to CVDs, the corresponding and overall scores were respectively summed up, log-transformed and categorized based on tertile distributions $($ lower $=$ poor $/$ middle $=$ aver age/upper $=$ good level of knowledge).

Self-perceptions regarding body-weight (normal/underweight/overweight), future risk for CVDs (yes/no) and overall health (poor/average/good) were also assessed.

To understand the exercise habit, type of activity and corresponding duration were enquired. Based on guideline of World Health Organization (WHO) for adolescent health [30], moderate to vigorous activity for at least $60 \mathrm{~min} /$ day on average was considered as adequate exercise.

On the other hand, to elicit the eating habit and related behavior, frequency of major meals/day (1-2/3/>3 times), frequency of snacking $(\leq 3 / 4 />4$ times), history of skipping meals (never/sometimes/often) and history of eating outside home (never/sometimes/often) were recorded. Average frequency of food intake for five times (including meals and snacks) was regarded as approximately appropriate as per the standard recommendations [31, 32]. Overall eating habit was determined by scoring the relatively poorer eating habits (captured based on inappropriate frequency of intake, skipping meals and eating fast foods) [31-34], in descending order and then after logtransformation of the scores, categorization as per the tertile distribution similarly as knowledge.

\section{Statistical analysis}

Descriptive analyses of the study variables were performed to determine the mean (for age) and proportions (for categorical variables) with corresponding $95 \%$ confidence intervals $(\mathrm{CI})$. Bivariate and multiple (adjusting for age, gender, SES and family history) regression analyses were performed next to measure the associations [odds ratio (OR) for bivariate and adjusted odds ratios (AOR) for multiple logistic regressions] of sociodemographic characteristics/knowledge/perceptions with exercise habit and dietary practices as well as between knowledge and perceptions regarding CVDs. Multinomial logistic regression was used when outcome variables having more than two categories. SAS version 9.3.2 was used for all statistical analyses. 


\section{Results}

Of 1755 invited students, 1652 did participate in our study (response rate of $94.1 \%$ ). The mean age was 14.2 years. Proportion of females was slightly higher than males. Nearly two-third of the participants belonged to middle class families. Positive family history of CVDs was reported by about one-fifth of the students. While the majority had poor overall knowledge regarding CVDs and their preventions, a small proportion was found to have good knowledge. Domain-wise, the majority of the students had poor knowledge about CVDs, their risk factors, prevention, high blood pressure and related abnormalities as well as healthy nutritional habits. More than half of the students perceived their body weight as normal while less than a quarter perceived themselves as overweight. Less than a third of the interviewed subjects were engaged in regular moderate-to-vigorous exercise and adequate (at least $1 \mathrm{~h}$ ) daily physically activity. Regarding dietary history, frequent snacking (four times or more/day) and eating street-foods (in the last week) were quite common (reported by more than half and one third respectively). On the other hand, consumption of more than three major meals/day and frequent skipping of meals were reported by more than $10 \%$. Based on their dietary history, more than half of participants were found to have overall poor eating-habits (Table 1).

Better knowledge (compared to poor, average or good knowledge) regarding CVDs in general, its risk factors, prevention and healthy eating among these urban adolescent school-goers was associated with having the perception regarding future risk of CVDs [for good knowledge respective Adjusted Odds Ratio, AORs were: $1.59(1.05-2.39), \quad 2.51(1.64-3.85), 2.13(1.35-3.35)$ and 1.85(1.22-2.81)] (Table 2).

Compared to females, male students were more likely to perform moderate/vigorous activities as were those who had better (compared to poor) knowledge regarding raised blood pressure [AOR respectively: 3.40(2.55-4.54) and 1.39(1.03-1.88)]. Students belonging to upper SES had lower odds of being involved in such activities compared to their counterparts belonging to lower SES $[\mathrm{AOR}=0.59(0.37-0.94)]$.

Regarding duration of exercise, older subjects were less likely to be physically active for at least $1 \mathrm{~h}$ per day $[\mathrm{AOR}=0.77(0.64-0.94)]$. Compared to females, male students were physically more active $[\mathrm{AOR}=7.77(4.61-$ 13.07)]. Good knowledge regarding overall CVD, its risk factors and healthy eating was also associated with higher odds of being physically active for adequate duration [AORs respectively: 2.90(1.46-5.78), 2.06(1.09-3.90) and 2.23(1.12-4.40)] (Table 3).

Increase in age was associated with intake of higher number of meals $\left[\mathrm{AOR}_{3}\right.$ meals $=1.27(1.08-1.51)$ and $\mathrm{AOR}>3$ meals $=1.27(1.01-1.59)$, reference $=1-2$ meals $]$.
Compared to females, males had higher frequency of major meals and snacking $[\mathrm{AOR}>3$ meals $=1.53(1.02-2.30)$, reference $=1 / 2$ meals; $\mathrm{AOR}_{4}$ times snacking $=1.61(1.23-2.10)$ and $\mathrm{AOR}>4$ times snacking $=1.68(1.04-2.71)$, reference $=\leq 3$ times]. Male students were also less likely to skip meals $[\mathrm{AOR}=0.62(0.42-0.93)$, reference $=$ never $]$. With reference to those belonging to lower SES, affluent participants had higher likelihood of taking more meals/day $\left[\mathrm{AOR}_{3}\right.$ meals $=8.67(5.26-14.29)$ and AOR $>3$ meals $=11.90(5.01-$ 28.29), reference $=1 / 2$ meals] and eating food outside. $\left[\mathrm{AOR}_{\text {sometimes }}=2.78(1.18-6.53)\right.$, reference $=$ never $]$ Regarding snacking habit, students belonging to higher SES were also likely to have less frequency $\left[\mathrm{AOR}_{4}\right.$ times $=0.57(0.37-0.87)$ and AOR $>{ }_{4}$ times $=0.20(0.09$ $0.49)$, reference $=$ never] .

Participants who had better knowledge (reference poor) regarding CVDs in general, its risk factors, healthy eating habits and overall about CVD with its prevention were more likely to eat $>3$ major meals/day [respective AORs: $1.74(1.07-2.84), \quad 2.17(1.34-3.53), \quad 2.08(1.26-3.43)$ and 2.90(1.72-4.88)]. With the same reference, participants with good knowledge regarding healthy nutritional habits had higher odds of snacking [AOR $=1.55(1.09-2.22)]$.

Subjects who perceived themselves to be overweight were less likely to take higher number of meals per day $\left[\mathrm{AOR}_{3}\right.$ meals $=0.63(0.45-0.89)$ and $\mathrm{AOR}>3$ meals $=0.42(0.25-0.70)$, ref. $=1 / 2$ meals $]$ and to eat outside $[\mathrm{AOR}=0.45(0.28-0.72)]$ relative to who perceived themselves as normal weight. Individuals who perceived themselves at risk for future CVDs were more likely to take $>3$ meals per day $[\mathrm{AOR}=1.62(1.02-2.58)]$ and skip meals $[\mathrm{AOR}=2.04(1.28-3.25)]$ than those who did not perceive themselves to be at risk (Table 4).

Overall frequency of eating increased with age $[\mathrm{AOR}>$ appropriate $=1.24(1.05-1.47)$, reference $=5$ times $]$. Considering major meals and snacking together, participants with good knowledge regarding risk factors $[$ AOR $=1.84(1.17-2.91)]$, healthy nutritional habits $[\mathrm{AOR}=1.69(1.05-2.71)]$ as well as overall good knowledge $[\mathrm{AOR}=2.19(1.34-3.58)$ ] were more likely to take food $>5$ times/day than those with poor knowledge.

Older students $\left[\mathrm{AOR}_{\text {average }}=0.82(0.69-0.98)\right.$ and AORgood $=0.70(0.56-0.89)]$, those from higher SES $[\mathrm{AOR}=0.23(0.11-0.47)]$, who had overall good knowledge regarding CVDs and their prevention $[\mathrm{AOR}=0.55(0.32-$ $0.94)$ ] and perceived themselves to be at higher risk for future CVDs $[$ AOR $=0.54(0.36-0.80)]$ were less likely to practice healthy eating behaviors. (Table 5).

\section{Discussion}

Current distribution reveals that persons belonging to 10-24 years age-group (1.8 billion) constitute the largest component of the global population and 1.5 billion of them hail from resource-poor settings [25, 35]. Adoption 
Table 1 Distribution of the study variables among participating adolescent school-students of Kolkata $(N=1652)$

\begin{tabular}{|c|c|c|c|c|}
\hline \multicolumn{2}{|l|}{ Continuous variables } & \multicolumn{2}{|l|}{ Number } & \multirow{2}{*}{$\begin{array}{l}\text { Mean }\left(95 \% \mathrm{Cl}^{\mathrm{a}}\right) \\
14.2(14.1-14.2)\end{array}$} \\
\hline Age in years & & 1652 & & \\
\hline Categorical variables & & Categories & Number & Percentage $(95 \% \mathrm{Cl})$ \\
\hline \multirow[t]{7}{*}{ Other socio-demographic factors } & \multirow[t]{2}{*}{ Gender of student } & Female & 885 & $53.6(51.2-56.0)$ \\
\hline & & Male & 767 & $46.4(44.0-48.8)$ \\
\hline & \multirow[t]{3}{*}{ Socio-economic status } & Lower & 276 & 17.0(15.2-18.8) \\
\hline & & Middle & 1012 & $62.3(60.0-64.7)$ \\
\hline & & Upper & 336 & 20.7(18.7-22.7) \\
\hline & \multirow[t]{2}{*}{ Family history of death due to $C^{C V}$} & No & 854 & $78.7(76.3-81.2)$ \\
\hline & & Yes & 231 & 21.3(18.9-23.7) \\
\hline \multirow[t]{18}{*}{ Level of knowledge regarding } & \multirow[t]{3}{*}{ CVD in general } & Poor & 677 & $41.0(38.6-43.4)$ \\
\hline & & Average & 603 & $36.5(34.2-38.8)$ \\
\hline & & Good & 372 & $22.5(20.5-24.5)$ \\
\hline & \multirow[t]{3}{*}{ Blood pressure and its abnormalities } & Poor & 965 & $58.4(56.0-60.8)$ \\
\hline & & Average & 499 & $30.2(28.0-32.4)$ \\
\hline & & Good & 188 & $11.4(9.9-12.9)$ \\
\hline & \multirow[t]{3}{*}{ Risk factors for CVDs } & Poor & 662 & $40.1(37.7-42.4)$ \\
\hline & & Average & 607 & $36.7(34.4-39.1)$ \\
\hline & & Good & 383 & $23.2(21.2-25.2)$ \\
\hline & \multirow[t]{3}{*}{ Prevention of CVDs } & Poor & 856 & $51.8(49.4-54.2)$ \\
\hline & & Average & 565 & $34.2(31.9-36.5)$ \\
\hline & & Good & 231 & $14.0(12.3-15.7)$ \\
\hline & \multirow[t]{3}{*}{ Healthy nutritional habits } & Poor & 847 & $51.3(48.9-53.7)$ \\
\hline & & Average & 524 & $31.7(29.5-34.0)$ \\
\hline & & Good & 281 & 17.0(15.2-18.8) \\
\hline & \multirow[t]{3}{*}{ CVD and their prevention (Overall) } & Poor & 719 & 43.5(41.1-45.9) \\
\hline & & Average & 647 & $39.2(36.8-41.5)$ \\
\hline & & Good & 286 & 17.3(15.5-19.1) \\
\hline \multirow[t]{9}{*}{ Self-perception about } & \multirow[t]{4}{*}{ Own body size } & Normal & 961 & $58.7(56.4-61.1)$ \\
\hline & & Underweight & 288 & 17.6(15.8-19.5) \\
\hline & & Overweight & 387 & $23.7(21.6-25.7)$ \\
\hline & & Obese & - & - \\
\hline & \multirow[t]{2}{*}{ Own future risk of CVDs } & No & 1324 & 81.8(79.9-83.7) \\
\hline & & Yes & 295 & 18.2(16.3-20.1) \\
\hline & \multirow[t]{3}{*}{ Own overall health } & Good & 993 & $60.5(58.1-62.8)$ \\
\hline & & Average & 573 & $34.9(32.6-37.2)$ \\
\hline & & Poor & 76 & $4.63(3.61-5.65)$ \\
\hline \multirow[t]{5}{*}{ Exercise } & \multirow[t]{2}{*}{ Moderate and Vigorous Activity } & No & 1171 & $71.0(68.8-73.2)$ \\
\hline & & Yes & 479 & $29.0(26.8-31.2)$ \\
\hline & \multirow[t]{3}{*}{ Exercise } & No Exercise & 197 & 12.0(10.4-13.6) \\
\hline & & Inadequate & 965 & $58.8(56.4-61.2)$ \\
\hline & & Adequate & 479 & $29.2(27.0-31.4)$ \\
\hline \multirow[t]{3}{*}{ Dietary history } & \multirow[t]{3}{*}{ Meals taken/day } & One/two & 867 & $52.6(50.2-55.0)$ \\
\hline & & Three & 596 & $36.1(33.8-38.5)$ \\
\hline & & > Three & 186 & 11.3(9.8-12.8) \\
\hline
\end{tabular}


Table 1 Distribution of the study variables among participating adolescent school-students of Kolkata ( $N=1652)$ (Continued)

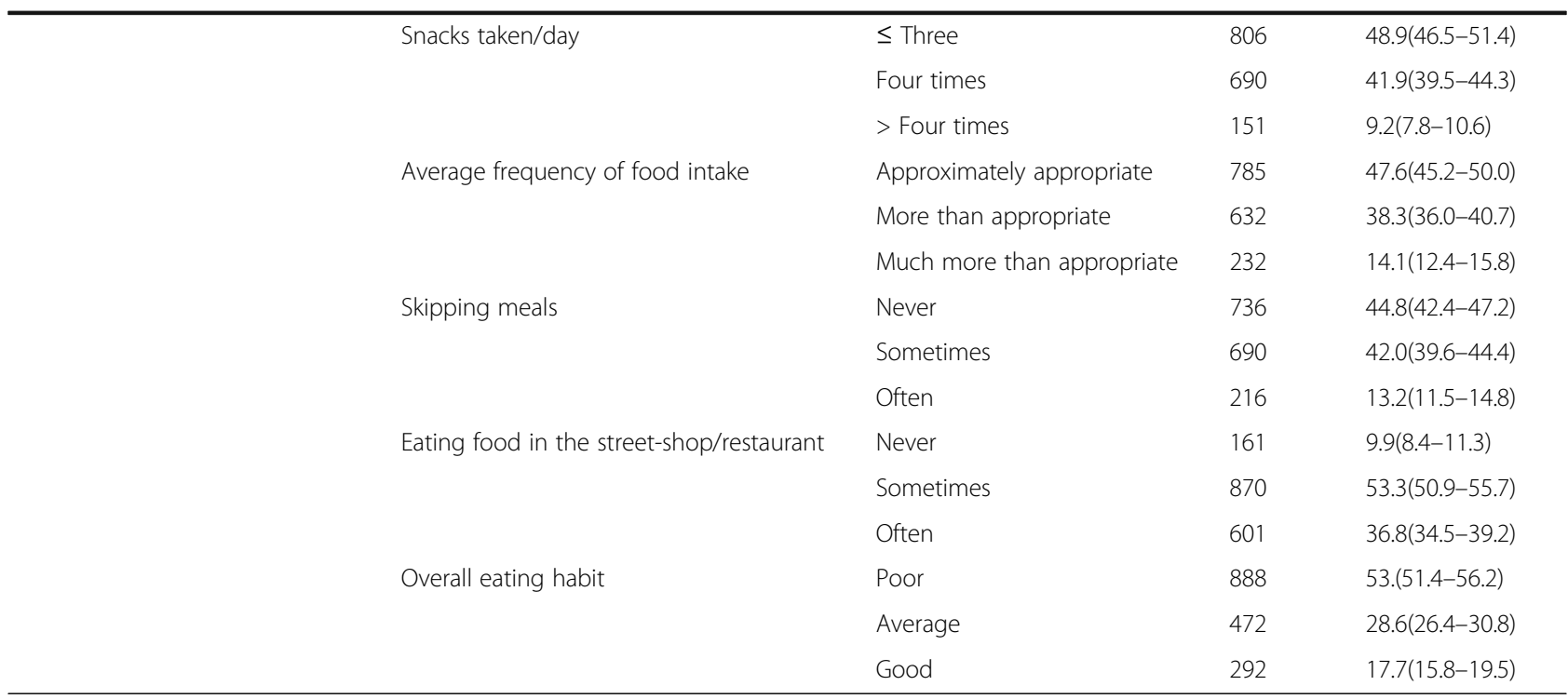

a $\mathrm{Cl}$ Confidence intervals

${ }^{\mathrm{b}}$ SES Socio-economic status of the families of the students

c CVD Cardio-vascular diseases

of healthy behaviors during adolescence is expected to serve as the foundation for ensuring longer life expectancy for this population group. Adolescence is considered as the period of vulnerability as well as the optimum opportunity to modify health-related risk behaviors [35]. On the contrary, young adults are always considered to be healthy and global health planners mostly neglect their health needs. Although some standardized health indicators are available for young in Western countries, such indicators are almost nonexistent in developing world. Moreover, adolescents' risk perceptions in relation to health-related behaviors appears to be crucial in determining long-term health consequences [36-41]. Thus, educating adolescents regarding negative impacts of risktaking and encouraging them to take responsibility of their own health seemed crucial in controlling adolescent health situation in countries like India.

\section{Knowledge regarding CVDs and their prevention}

In this relatively large cross-sectional study, involving adolescent school-students of a metro city (Kolkata) in India, overall knowledge regarding CVDs and their prevention was observed to be poor among participants. The level of knowledge varied considerably across domains. About $60 \%$ students had average/good knowledge regarding CVDs in general. Similar findings were also reported from other states in India [42, 43] In our study about $23 \%$ of participants had good knowledge regarding risk factors for CVDs. Knowledge regarding lifestyle risk factors of NCDs was observed to be even lower among students in Kerala [44], as well as in Michigan [21] and Arizona [45] in US but relatively higher in
Nepal [46]. A significant proportion of students in Pune reported obesity, physical inactivity and smoking as predictors of CVDs but could not identify other potential risk factors like serum cholesterol and hypertension [42]. Innovative and friendly educational intervention strategies should be developed for youth so that the gaps in knowledge about CVDs could be addressed successfully.

\section{Perceptions}

Understanding the risk-associated thoughts and response was found to be fundamental in shaping perceptions to promote healthy behaviors. Slovic suggested that unfamiliar risks (new/unknown) were mostly avoided by people whereas familiar risks if perceived as controllable or selfchosen culminated into reduction of importance [47]. In addition, body image perception of adolescents and resultant dissatisfaction might negatively affect adolescent health behaviors [48, 49]. In our study, only $23.7 \%$ perceived themselves as overweight and they demonstrated relatively healthy eating habits. Care should also be taken to ensure that youth perception of overweight does not culminate into depression and harmful weight control practices.

About $82 \%$ of the participating adolescents did not perceive themselves to be at risk for future CVDs and even those who perceived the risk showed poor dietary practices. Similar findings were also reported from Nepal and Michigan (US) [21, 46]. One of the probable explanations might be that adolescents considered CVDs to be old age related problem and underestimated their future risks. We also observed that subjects with average/good knowledge regarding CVDs were more likely 


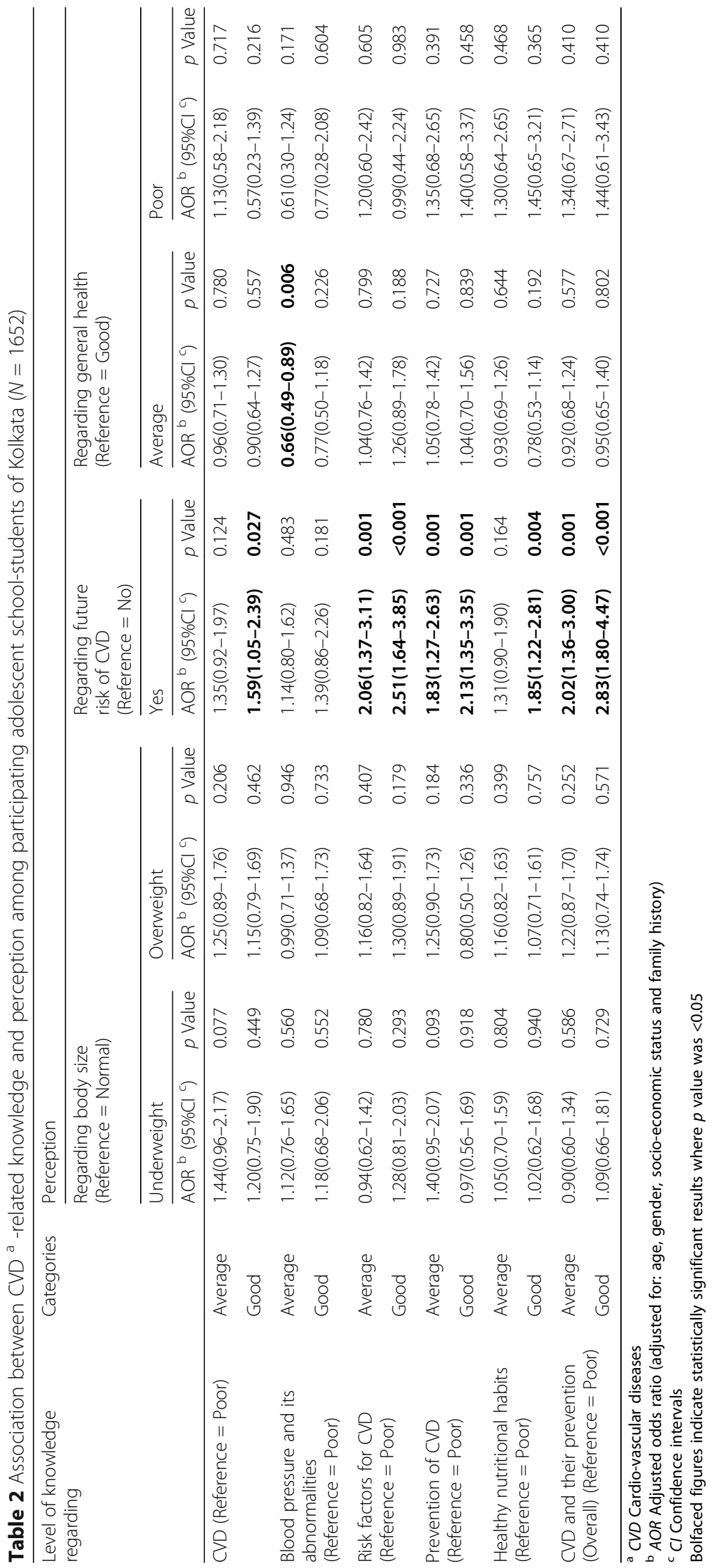




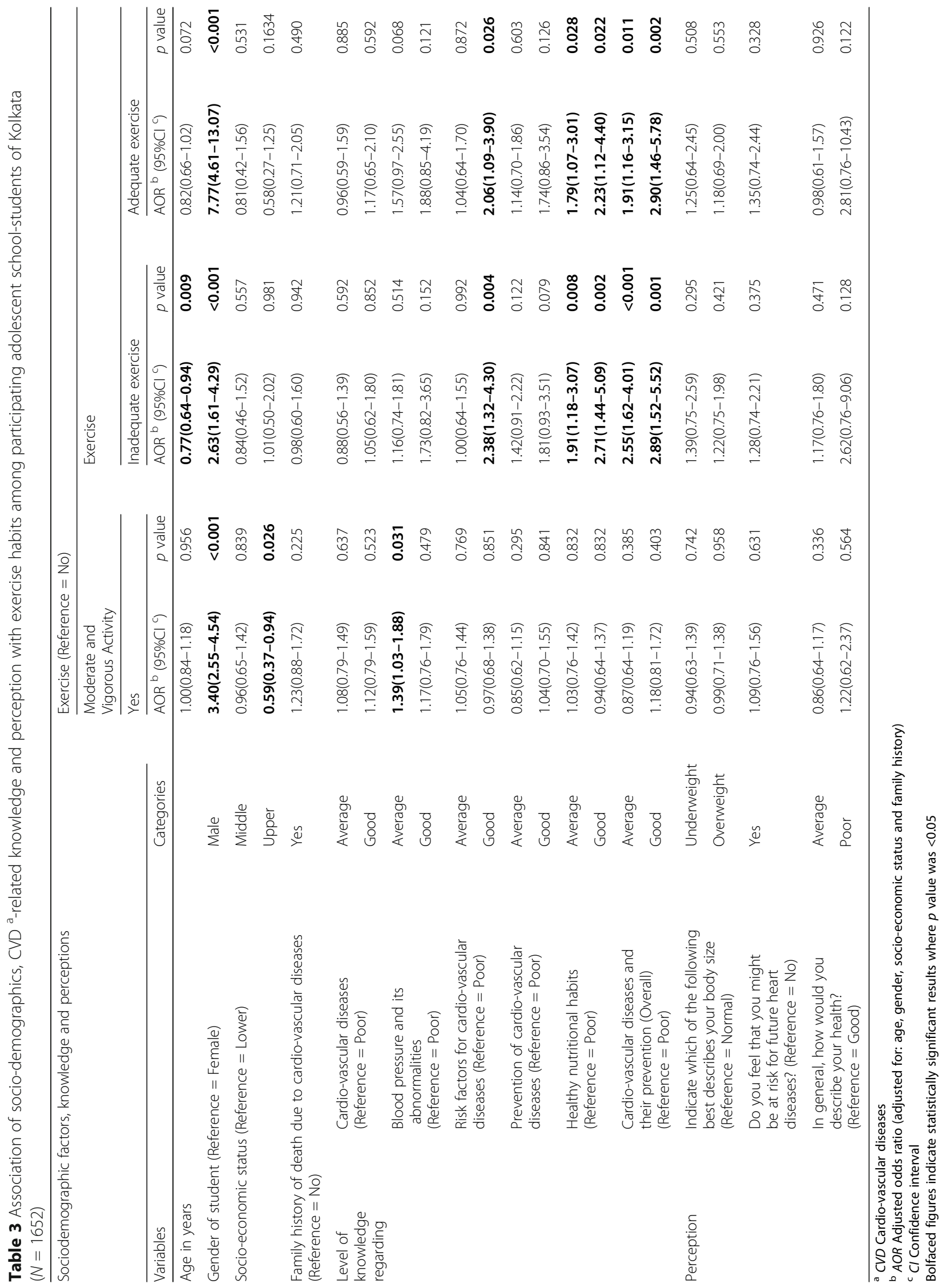


(compared to those with poor knowledge) to perceive themselves at risk for future CVDs. Promotion of school-based cardiovascular health programs might be crucial in dispelling myths and misconceptions with eventual prevention of early onset atherosclerotic changes in arterial walls.

\section{Positive family history}

Consistent with previous studies [43], little above onefifth participants had positive family history of CVDs while in Kerala about $2.9 \%$ had such history [44]. Early screening of these at-risk children and appropriate interventions might be effective in prevention of early onset CVDs.

\section{Physical activity}

Less than 30\% subjects reported to get engage in moderate-to-vigorous exercises regularly which was lower than that reported among school-aged children in Delhi [43] and in Gujarat [50] but higher than in Kerala [44]. Inadequate physical activity was also reported from Ontario, US [51] and in Uttarakhand, Maharashtra, Madhya Pradesh and Andhra Pradesh in India [52]. Consistent with previous research in Brazil [53] and Taiwan [35], male students were more likely to be physically active in our study. Previous studies suggested a probable decline in physical activity during transition from adolescence into adulthood, especially between 15 and 23 years $[54,55]$. One of the probable reasons might be that as adolescents get

Table 4 Association of socio-demographics, CVD ${ }^{\text {a }}$-related knowledge and perception with components of eating habits among participating adolescent school-students of Kolkata $(N=1652)$

\begin{tabular}{|c|c|c|c|c|c|c|c|c|c|c|}
\hline \multirow{2}{*}{\multicolumn{3}{|c|}{$\begin{array}{l}\text { Socio-demographics, } \\
\text { knowledge } \\
\text { and perception }\end{array}$}} & \multicolumn{4}{|c|}{$\begin{array}{l}\text { Meals taken/day } \\
\text { (Reference = One/two) }\end{array}$} & \multicolumn{4}{|c|}{$\begin{array}{l}\text { Snacks taken/day? } \\
\text { (Reference = Three } \\
\text { times or less) }\end{array}$} \\
\hline & & & \multicolumn{2}{|l|}{ Three } & \multicolumn{2}{|l|}{ More than three } & \multicolumn{2}{|l|}{ Four times } & \multicolumn{2}{|l|}{$\begin{array}{l}\text { More than } \\
\text { four times }\end{array}$} \\
\hline Variables & & Categories & $\mathrm{AOR}^{\mathrm{b}}\left(95 \% \mathrm{Cl}^{\mathrm{c}}\right)$ & $\overline{p \text { value }}$ & $\begin{array}{l}\mathrm{AOR}{ }^{\mathrm{b}} \\
\left(95 \% \mathrm{Cl}^{\mathrm{c}}\right)\end{array}$ & $\overline{p \text { value }}$ & $\begin{array}{l}\mathrm{AOR}{ }^{\mathrm{b}} \\
\left(95 \% \mathrm{Cl}^{\mathrm{c}}\right)\end{array}$ & $\overline{p \text { value }}$ & $\begin{array}{l}\mathrm{AOR}{ }^{\mathrm{b}} \\
\left(95 \% \mathrm{Cl}^{\mathrm{c}}\right)\end{array}$ & $p$ value \\
\hline Age in years & & & $1.27(1.08-1.51)$ & 0.004 & $1.27(1.01-1.59)$ & 0.044 & $0.90(0.77-1.05)$ & 0.184 & $0.93(0.71-1.22)$ & 0.616 \\
\hline \multirow{4}{*}{$\begin{array}{l}\text { Other socio- } \\
\text { demographic } \\
\text { factors }\end{array}$} & $\begin{array}{l}\text { Gender of student } \\
\text { (Reference = Female) }\end{array}$ & Male & $1.05(0.79-1.41)$ & 0.739 & $1.53(1.02-2.30)$ & 0.039 & $1.61(1.23-2.10)$ & $<0.001$ & $1.68(1.04-2.71)$ & 0.034 \\
\hline & Socio-economic & Middle & $1.91(1.24-2.93)$ & 0.003 & $3.62(1.61-8.10)$ & 0.002 & $0.86(0.59-1.26)$ & 0.447 & $0.74(0.41-1.34)$ & 0.314 \\
\hline & $\begin{array}{l}\text { status } \\
\text { (Reference }=\text { Lower) }\end{array}$ & Upper & $8.67(5.26-14.29)$ & $<0.001$ & $11.90(5.01-28.29)$ & $<0.001$ & $0.57(0.37-0.87)$ & 0.010 & $0.20(0.09-0.49)$ & $<0.001$ \\
\hline & $\begin{array}{l}\text { Family history of } \\
\text { death due to CVD } \\
\text { (Reference }=\text { No) }\end{array}$ & Yes & $0.92(0.65-1.30)$ & 0.624 & $0.89(0.54-1.48)$ & 0.657 & $1.06(0.77-1.46)$ & 0.704 & $1.27(0.75-2.16)$ & 0.374 \\
\hline \multirow{12}{*}{$\begin{array}{l}\text { Level of } \\
\text { knowledge } \\
\text { regarding }\end{array}$} & \multirow{2}{*}{$\begin{array}{l}\text { CVD } \\
\text { (Reference = Poor) }\end{array}$} & Average & $1.46(1.05-2.01)$ & 0.023 & $1.42(0.89-2.27)$ & 0.145 & $0.80(0.60-1.08)$ & 0.146 & $1.16(0.68-1.98)$ & 0.592 \\
\hline & & Good & $1.24(0.86-1.79)$ & 0.245 & $1.74(1.07-2.84)$ & 0.027 & $1.04(0.75-1.45)$ & 0.799 & $1.25(0.68-2.29)$ & 0.477 \\
\hline & \multirow{2}{*}{$\begin{array}{l}\text { Blood pressure } \\
\text { and its abnormalities } \\
\text { (Reference = Poor) }\end{array}$} & Average & $1.42(1.13-1.80)$ & 0.003 & $1.53(1.07-2.18)$ & 0.021 & $0.91(0.72-1.15)$ & 0.421 & $1.23(0.84-1.79)$ & 0.289 \\
\hline & & Good & $1.12(0.71-1.77)$ & 0.627 & $1.76(1.00-3.11)$ & 0.051 & $0.94(0.63-1.41)$ & 0.779 & $0.75(0.33-1.68)$ & 0.482 \\
\hline & \multirow{2}{*}{$\begin{array}{l}\text { Risk factors for CVD } \\
\text { (Reference = Poor) }\end{array}$} & Average & $1.51(1.09-2.09)$ & 0.014 & $1.18(0.73-1.90)$ & 0.509 & $1.03(0.76-1.39)$ & 0.867 & $1.26(0.75-2.14)$ & 0.385 \\
\hline & & Good & $1.93(1.34-2.78)$ & 0.001 & $2.17(1.34-3.53)$ & 0.002 & $1.11(0.80-1.55)$ & 0.530 & $0.93(0.49-1.76)$ & 0.824 \\
\hline & \multirow{2}{*}{$\begin{array}{l}\text { Prevention of CVD } \\
\text { (Reference = Poor) }\end{array}$} & Average & $1.28(0.94-1.75)$ & 0.118 & $1.41(0.91-2.17)$ & 0.122 & $1.12(0.84-1.50)$ & 0.430 & $1.37(0.81-2.31)$ & 0.243 \\
\hline & & Good & $1.81(1.20-2.74)$ & 0.005 & $1.64(0.93-2.89)$ & 0.087 & $0.95(0.65-1.39)$ & 0.787 & $1.64(0.85-3.19)$ & 0.142 \\
\hline & \multirow{2}{*}{$\begin{array}{l}\text { Healthy nutritional } \\
\text { habits } \\
\text { (Reference = Poor) }\end{array}$} & Average & $1.32(0.96-1.82)$ & 0.086 & $1.18(0.75-1.88)$ & 0.476 & $1.22(0.91-1.64)$ & 0.189 & $1.03(0.60-1.78)$ & 0.912 \\
\hline & & Good & $1.46(0.99-2.16)$ & 0.058 & $2.08(1.26-3.43)$ & 0.004 & $1.55(1.09-2.22)$ & 0.015 & $1.35(0.71-2.57)$ & 0.355 \\
\hline & \multirow{2}{*}{$\begin{array}{l}\text { CVD and their } \\
\text { prevention (Overall) } \\
\text { (Reference = Poor) }\end{array}$} & Average & $1.57(1.14-2.15)$ & 0.006 & $1.14(0.72-1.82)$ & 0.583 & $0.98(0.73-1.31)$ & 0.888 & $0.91(0.54-1.54)$ & 0.736 \\
\hline & & Good & $2.36(1.57-3.54)$ & $<0.001$ & $2.90(1.72-4.88)$ & $<0.001$ & $1.29(0.89-1.85)$ & 0.177 & $1.17(0.60-2.27)$ & 0.652 \\
\hline \multirow{5}{*}{$\begin{array}{l}\text { Perception } \\
\text { regarding }\end{array}$} & \multirow{2}{*}{$\begin{array}{l}\text { Own body size } \\
\text { (Reference }=\text { Normal) }\end{array}$} & Underweight & $1.03(0.69-1.53)$ & 0.890 & $0.54(0.28-1.03)$ & 0.063 & $1.28(0.88-1.85)$ & 0.192 & $0.92(0.47-1.79)$ & 0.800 \\
\hline & & Overweight & $0.63(0.45-0.89)$ & 0.008 & $0.42(0.25-0.70)$ & 0.001 & $1.18(0.87-1.61)$ & 0.292 & $0.93(0.52-1.65)$ & 0.802 \\
\hline & $\begin{array}{l}\text { Future risk of CVDs } \\
\text { (Reference }=\mathrm{No} \text { ) }\end{array}$ & Yes & $0.93(0.64-1.35)$ & 0.698 & $1.62(1.02-2.58)$ & 0.042 & $0.94(0.67-1.32)$ & 0.721 & $1.16(0.65-2.08)$ & 0.615 \\
\hline & \multirow{2}{*}{$\begin{array}{l}\text { Own overall health } \\
\text { (Reference = Good) }\end{array}$} & Average & $0.89(0.66-1.21)$ & 0.470 & $1.16(0.76-1.76)$ & 0.496 & $1.19(0.90-1.57)$ & 0.225 & $1.19(0.72-1.97)$ & 0.498 \\
\hline & & Poor & $0.81(0.40-1.63)$ & 0.552 & $1.05(0.40-2.72)$ & 0.925 & $1.25(0.65-2.42)$ & 0.503 & $2.45(0.96-6.23)$ & 0.061 \\
\hline
\end{tabular}

${ }^{a}$ CVD Cardio-vascular diseases ${ }^{\mathrm{b}} \mathrm{AOR}$ Adjusted odds ratio (adjusted for: age, gender, socio-economic status and family history) ${ }^{\mathrm{c}} \mathrm{Cl}$ Confidence interval Bolfaced figures indicate statistically significant results where $p$ value was $<0.05$ 
Table 4 Association of socio-demographics, CVD ${ }^{\text {a }}$-related knowledge and perception with components of eating habits among participating adolescent school-students of Kolkata ( $N=1652)$ (Continued)

\begin{tabular}{|c|c|c|c|c|c|c|c|c|}
\hline \multirow{3}{*}{$\begin{array}{l}\text { Socio-demographics, } \\
\text { knowledge } \\
\text { and perception } \\
\text { Variables }\end{array}$} & \multicolumn{4}{|c|}{$\begin{array}{l}\text { Skipping meals } \\
\text { (Reference = Never) }\end{array}$} & \multicolumn{4}{|c|}{$\begin{array}{l}\text { Eating food in the street-shop/restaurant } \\
\text { (Reference }=\text { Never) }\end{array}$} \\
\hline & \multicolumn{2}{|l|}{ Sometimes } & \multicolumn{2}{|l|}{ Often } & \multicolumn{2}{|l|}{ Sometimes } & \multicolumn{2}{|l|}{ Often } \\
\hline & $\begin{array}{l}\mathrm{AOR}{ }^{\mathrm{b}} \\
\left(95 \% \mathrm{Cl}^{\mathrm{c}}\right)\end{array}$ & $p$ value & $\begin{array}{l}\mathrm{AOR}{ }^{\mathrm{b}} \\
\left(95 \% \mathrm{Cl}^{\mathrm{c}}\right)\end{array}$ & $p$ value & $\begin{array}{l}\mathrm{AOR}{ }^{\mathrm{b}} \\
\left(95 \% \mathrm{Cl}^{\mathrm{c}}\right)\end{array}$ & $p$ value & $\mathrm{AOR}^{\mathrm{b}}\left(95 \% \mathrm{Cl}^{\mathrm{c}}\right)$ & $p$ value \\
\hline Age in years & $1.05(0.89-1.23)$ & 0.572 & $1.11(0.90-1.37)$ & 0.328 & $1.20(0.90-1.59)$ & 0.206 & $1.26(0.95-1.69)$ & 0.113 \\
\hline \multirow{4}{*}{$\begin{array}{l}\text { Other socio- } \\
\text { demographic } \\
\text { factors }\end{array}$} & $0.80(0.61-1.04)$ & 0.099 & $0.62(0.42-0.93)$ & 0.021 & $1.06(0.68-1.66)$ & 0.790 & $1.32(0.83-2.10)$ & 0.234 \\
\hline & $0.87(0.60-1.28)$ & 0.482 & $0.77(0.45-1.33)$ & 0.348 & $0.87(0.45-1.66)$ & 0.667 & $0.45(0.24-0.85)$ & 0.015 \\
\hline & $1.29(0.83-2.00)$ & 0.257 & $1.06(0.56-1.98)$ & 0.862 & $2.78(1.18-6.53)$ & 0.019 & $1.04(0.44-2.47)$ & 0.934 \\
\hline & $1.20(0.87-1.66)$ & 0.275 & $1.16(0.72-1.86)$ & 0.541 & $0.94(0.56-1.56)$ & 0.802 & $1.09(0.64-1.84)$ & 0.750 \\
\hline \multirow{12}{*}{$\begin{array}{l}\text { Level of } \\
\text { knowledge } \\
\text { regarding }\end{array}$} & $1.10(0.81-1.49)$ & 0.536 & $1.15(0.74-1.78)$ & 0.538 & $0.78(0.48-1.28)$ & 0.330 & $0.67(0.41-1.12)$ & 0.130 \\
\hline & $1.21(0.87-1.70)$ & 0.256 & $1.02(0.61-1.69)$ & 0.947 & $0.88(0.50-1.55)$ & 0.658 & $0.76(0.42-1.36)$ & 0.355 \\
\hline & $1.14(0.90-1.43)$ & 0.282 & $1.00(0.71-1.41)$ & 1.000 & $1.35(0.91-1.99)$ & 0.134 & $1.29(0.86-1.93)$ & 0.219 \\
\hline & $1.19(0.78-1.80)$ & 0.422 & $1.14(0.62-2.07)$ & 0.675 & $0.53(0.28-1.01)$ & 0.053 & $0.72(0.38-1.37)$ & 0.317 \\
\hline & $1.05(0.77-1.42)$ & 0.780 & $0.92(0.59-1.42)$ & 0.694 & $1.63(0.97-2.76)$ & 0.067 & $2.04(1.19-3.49)$ & 0.009 \\
\hline & $1.00(0.71-1.41)$ & 0.984 & $0.80(0.48-1.33)$ & 0.388 & $1.28(0.75-2.16)$ & 0.365 & $0.95(0.54-1.67)$ & 0.864 \\
\hline & $1.15(0.86-1.54)$ & 0.341 & $0.83(0.54-1.29)$ & 0.417 & $1.21(0.76-1.93)$ & 0.412 & $0.91(0.56-1.48)$ & 0.708 \\
\hline & $1.05(0.71-1.54)$ & 0.812 & $0.93(0.53-1.63)$ & 0.788 & $2.06(0.96-4.39)$ & 0.062 & $1.59(0.73-3.48)$ & 0.243 \\
\hline & $1.13(0.84-1.53)$ & 0.427 & $0.91(0.58-1.42)$ & 0.671 & $1.23(0.75-2.01)$ & 0.419 & $1.22(0.73-2.04)$ & 0.445 \\
\hline & $1.07(0.75-1.53)$ & 0.709 & $0.85(0.49-1.45)$ & 0.546 & $1.43(0.76-2.66)$ & 0.266 & $1.28(0.67-2.45)$ & 0.455 \\
\hline & $1.20(0.89-1.61)$ & 0.237 & $1.00(0.65-1.54)$ & 0.998 & $1.29(0.81-2.07)$ & 0.287 & $1.08(0.66-1.76)$ & 0.762 \\
\hline & $1.09(0.75-1.58)$ & 0.653 & $0.74(0.42-1.31)$ & 0.297 & $1.48(0.77-2.82)$ & 0.239 & $1.33(0.68-2.60)$ & 0.399 \\
\hline \multirow[t]{5}{*}{ Perception regarding } & $0.96(0.66-1.40)$ & 0.827 & $1.12(0.64-1.94)$ & 0.699 & $0.94(0.48-1.85)$ & 0.866 & $1.28(0.65-2.54)$ & 0.472 \\
\hline & $0.94(0.68-1.29)$ & 0.688 & $1.24(0.79-1.96)$ & 0.346 & $0.45(0.28-0.72)$ & 0.001 & $0.55(0.33-0.89)$ & 0.016 \\
\hline & $1.23(0.87-1.75)$ & 0.249 & $2.04(1.28-3.25)$ & 0.003 & $0.88(0.51-1.51)$ & 0.631 & $1.01(0.57-1.77)$ & 0.978 \\
\hline & $1.10(0.83-1.46)$ & 0.513 & $1.21(0.80-1.83)$ & 0.376 & $1.02(0.63-1.63)$ & 0.945 & $1.25(0.77-2.03)$ & 0.371 \\
\hline & $1.57(0.80-3.09)$ & 0.190 & $1.82(0.74-4.48)$ & 0.195 & $0.38(0.16-0.90)$ & 0.027 & $0.54(0.23-1.30)$ & 0.172 \\
\hline
\end{tabular}

older, they lack self-motivation and become less compliant to healthy advices. On the other hand we observed that students with good/average knowledge regarding CVDs were somewhat physically active. Based on this observation, it seemed reasonable to hypothesize that adolescents who were well informed about negative health effects of physical inactivity were possibly more motivated to be physically active.

\section{Eating habits}

More than half of the participants of the current study demonstrated poor eating-behaviors. Older subjects, males and those who were economically better-placed, took more than appropriate number of meals (major meals \& snacks). Similar observations were also reported among adolescents from Arab [56], Europe [57], China [58] and other states in India: Baroda [31], Mysore [30], Uttarakhand, Maharashtra, Kerala, Madhya Pradesh and Andhra Pradesh [52]. There were huge gaps between knowledge about CVDs and eating behavior among study participants. Subjects with good knowledge were likely to take higher number of meals and snacks per day. This observation might be explained by possible influence of frequency and pattern of eating in family. Friendly interactions between adolescents and their parents/teachers/nutritionists at regular interval might be effective in shaping their eating habits.

Although higher physical inactivity has often been linked with increased risk of morbidity and mortality, an estimated $60 \%$ of population in the world do not perform recommended exercise regularly. As per WHO estimates, $80 \%$ of premature heart diseases and $80 \%$ of diabetes could be prevented by interplay of healthy diet, physical activity and tobacco avoidance [35]. Moreover, analysis of Northern Finland birth cohort data revealed that risk of obesity was significantly lower in adolescents who ate five meals/day [32] while intake of inappropriate number of meals/day was associated with future development of obesity [59]. Thus, early identification of these unattended risk factors through screening, timely interventions and raising awareness about healthy lifestyle during adolescence might be more effective in controlling CVD epidemics in India. Furthermore, lifestyle modifications at younger age might be more successful than 


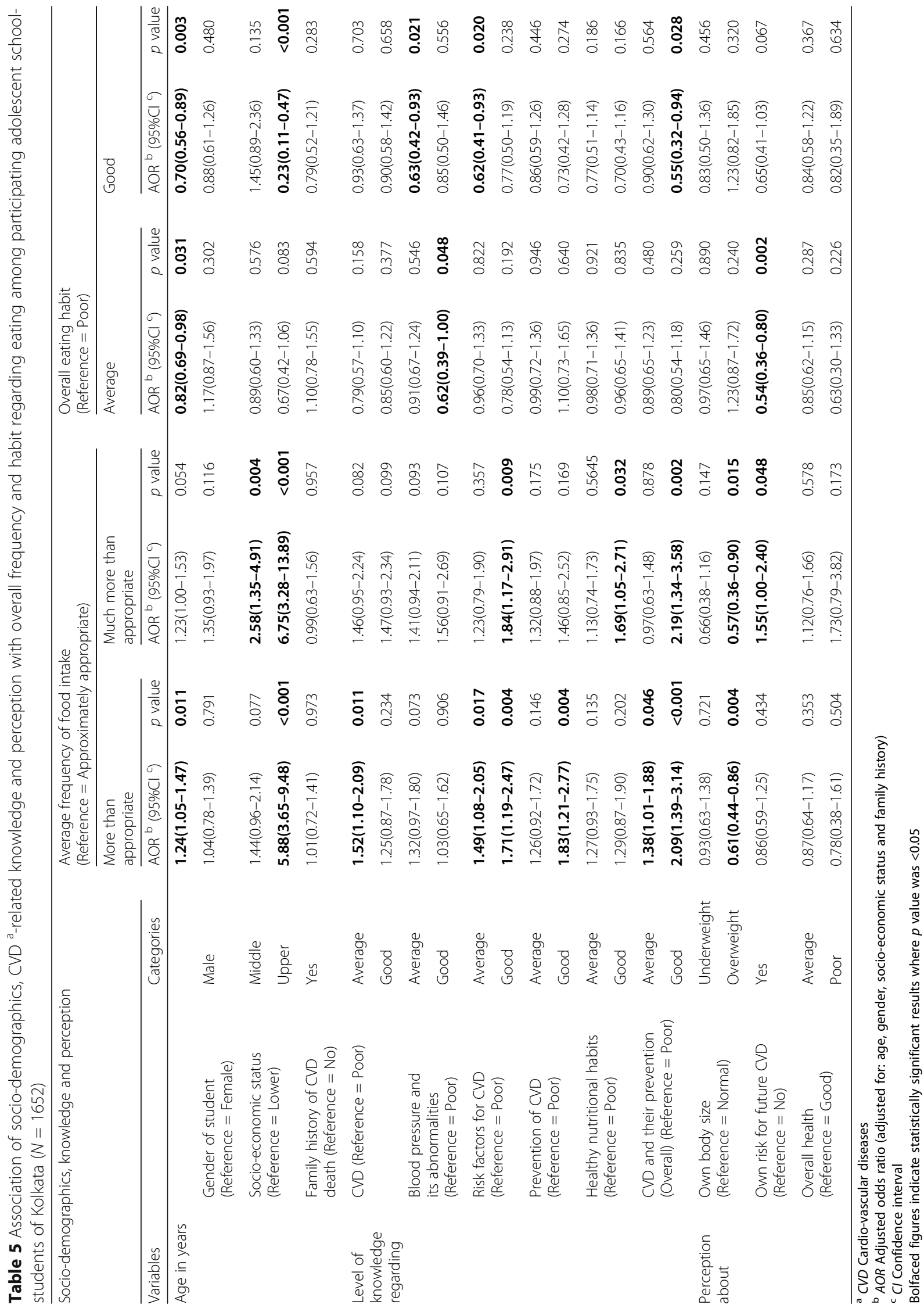


changing acquired harmful habits in adults. Thus, a concerted public health effort towards modifying food and physical activity environments in schools and in communities seemed to be the need of the hour.

\section{Study limitations}

There were some major limitations in the present study. Alike any other observational study associations observed here, should not be interpreted as causal owing to the potentials for residual confounding and other systematic errors. Because of the cross-sectional design, potentials for temporal ambiguity should also be kept in mind. Nonresponse might have affected the representativeness of the study population. Thus, efforts for extrapolation of results beyond the study sample to all adolescent urban students in the study area need some caution. But we still believe that the observations were quite generalizable, owing to the robust sampling strategy and good response rate. Selfreported history of dietary pattern and exercise habits were also likely to suffer from some social desirability bias and issues of recall, although we considered them to be non-differential. Moreover, to minimize the chances of information bias, we urged the subjects to recall for only a short period of 1 week. Despite these limitations, by virtue of large sample size, robust methodology and advanced statistical analyses, we believe that the results of this research will be useful in understanding the scenario pertaining to CVD related knowledge, perceptions regarding related risk, exercise habit, dietary practices and interplays thereof among adolescents of Kolkata, India.

\section{Conclusions}

Eating and exercise habits were found to be quite poor among large proportion of adolescent school-students of Kolkata. Lack of adequate knowledge and poor perception about CVD, related risk and importance of their prevention were potential contributors. Also, there existed a large gap between CVD-related knowledge and eating and exercise related practice. As such, our results suggest that there is a critical need for not only the improvement of knowledge and awareness regarding CVD and its related risks, but also actions that will help to bridge the knowledge-practice gap for eating and exercise habits. Given childhood origin of CVDs and possibility of reversing/slowing these atherosclerotic changes through early life style modifications, youth friendly, multicomponent cardiovascular health promotion programs are urgently required to raise awareness and appropriate translation of the awareness in to healthy practices in this target population.

\section{Abbreviations}

95\%Cl: 95\% confidence interval; AOR: Adjusted odds ratio; CVD: Cardiovascular disease(s); IHD: Ischemic heart disease(s); NCD: Non-communicable disease(s); OR: Odds ratio; SES: Socio-economic status

\section{Acknowledgements}

Authors express their sincere gratitude to The Department of school Education, Government of West Bengal for providing the necessary administrative support during the study. Authors are also thankful to Mission Arogya Health and Information Technology Research Foundation, Kolkata for conducting the study and the authorities, guardians and students of the participating schools for their kind co-operation and contribution regarding time and energy that made the collection of the information for this study possible.

\section{Funding}

This work was funded (reference no.: CSWB/CRRIS/13/339; 24.09.2013) by the Cardiological Society of India, West Bengal Branch. Funding body had no role in the design of the study and collection, analysis, and interpretation of data and in writing the manuscript.

\section{Availability of data and materials}

As the data contains individual personal information of the students and their families, it has not been posted to any repositories, as per the Ethical guidelines of the Institutional Ethics Committee of Barrackpur Population Health Research Foundation, Barrackpur. The dataset supporting the conclusions of this article is available freely from the CRRIS Study Research Team, Cardiological Society of India, West Bengal Branch. Researchers who meet the criteria for accessing confidential data need to contact at

csi_westbengal@eth.net or the corresponding author, using the following contact details:

Tanmay Mahapatra.

Mailing Address: 8 Dr. Ashutosh Sastri Road, Kolkata 700,010, West Bengal, India.

Telephone: $+918,017,206,285$.

Fax: $+913,325,926,904$

Email: drtanmaymahapatra@yahoo.com

\section{Authors' contributions}

SK conceptualized of the study, developed the protocol, designed the study and critically reviewed the final manuscript. SR participated in the conceptualization, protocol development and designing of the study and critically reviewed the final manuscript. DR, MKD, SG, PKD and AKB participated in the supervision of the study and critically reviewed the final manuscript. $K_{1}$ and $S D$ participated in the supervision of the study and critically reviewed the final manuscript. TM supervised the overall study conduct, analyzed the data, drafted the manuscript. SM participated in the supervision of the study, analysis of data, drafting of the manuscript and finalized the manuscript. KG and KC participated in the supervision of the study, analysis of data, drafting of the manuscript.

\section{Competing interests}

The authors declare that they have no competing interests.

\section{Consent for publication}

Not applicable.

\section{Ethics approval and consent to participate}

The study procedures and protocol were reviewed and approved (reference no.: BPHRF-IEC/13-14/008 DATED: 1.10.2013) by the Institutional Ethics Committee of Barrackpur Population Health Research Foundation, Barrackpur. Prior to the interview, after informing all details about the study in appropriate language, written voluntary assents and consents were respectively collected from each participating adolescent and their accompanying guardians (or their legally authorized representative). Data were securely preserved with confidentiality.

\section{Publisher's Note}

Springer Nature remains neutral with regard to jurisdictional claims in published maps and institutional affiliations.

\section{Author details}

'Department of Cardiology, Vivekananda Institute of Medical Sciences, Kolkata, West Bengal 700026, India. ${ }^{2}$ Department of Cardiology, Rabindranath Tagore International Institute of Cardiac Sciences, Kolkata, West Bengal 700099, India. ${ }^{3}$ Department of Cardiology, Nilratan Sircar Medical College and 
Hospital, Kolkata, West Bengal 700014, India. ${ }^{4}$ Department of Cardiology, Institute of Post-Graduate Medical Education and Research, Kolkata, West Bengal 700020, India. ${ }^{5}$ Fielding School of Public Health, University of California - Los Angeles, Los Angeles, CA 90095, USA. ${ }^{6}$ Mission Arogya Health and Information Technology Research Foundation, Kolkata, West Bengal 700010, India. ${ }^{7}$ Medica Institute of Cardiac Sciences, Medica Super Specialty Hospital, Kolkata, West Bengal 700099, India. ${ }^{8}$ Barrackpore Population Health Research Foundation, Kolkata, West Bengal 700123, India. 9The BM Birla Heart Research Centre, Kolkata, West Bengal 700027, India. ${ }^{10}$ Medical College and Hospital, Kolkata, West Bengal 700073, India. ${ }^{11}$ Charnock Hospitals Private Limited, Kolkata, West Bengal 700157, India. ${ }^{12}$ Fortis Hospitals Private Limited, Kolkata, West Bengal 700127, India. ${ }^{13}$ Mission Arogya Health and Information Technology Research Foundation, 8 Dr. Ashutosh Sastri Road, Kolkata, West Bengal 700010, India.

Received: 31 May 2016 Accepted: 8 May 2017

Published online: 18 May 2017

\section{References}

1. Cardiovascular diseases (CVDs), Fact sheet, Media centre, World Health Organization (WHO), 2016. http://www.who.int/mediacentre/factsheets/ fs317/en/. Accessed 12 May 2017.

2. Global status report on noncommunicable diseases 2014, World Health Organization (WHO), 2014. http://www.who.int/nmh/publications/ncdstatus-report-2014/en/. Accessed 13 May 2016.

3. Joshi P, Islam S, Pais P, Reddy S, Dorairaj P, Kazmi K, Pandey MR, Haque S, Mendis $S$, Rangarajan $S$, et al. Risk factors for early myocardial infarction in South Asians compared with individuals in other countries. JAMA. 2007;297(3):286-94.

4. Sasayama S. Heart disease in Asia. Circulation. 2008;118(25):2669-71.

5. Engelgau MM. Capitalizing on the demographic transition: tackling noncommunicable diseases in South Asia. World Bank Publications; 2011. http://siteresources.worldbank.org/SOUTHASIAEXT/Resources/2235461296680097256/7707437-1296680114157/NCDs_South_Asia_February_2011. pdf. Accessed 18 May 2016.

6. Gupta R, Joshi P, Mohan V, Reddy KS, Yusuf S. Epidemiology and causation of coronary heart disease and stroke in India. Heart. 2008;94(1):16-26.

7. Ajay VS, Prabhakaran D. Coronary heart disease in Indians: implications of the INTERHEART study. Indian J Med Res. 2010;132:561-6.

8. O'Keefe EL, DiNicolantonio JJ, Patil H, Helzberg JH, Lavie CJ. Lifestyle Choices Fuel Epidemics of Diabetes and Cardiovascular Disease among Asian Indians. Prog Cardiovasc Dis. 2015;58(5):505-13.

9. Yeo KK, Tai BC, Heng D, Lee JM, Ma S, Hughes K, Chew SK, Chia KS, Tai ES. Ethnicity modifies the association between diabetes mellitus and ischaemic heart disease in Chinese, Malays and Asian Indians living in Singapore. Diabetologia. 2006;49(12):2866-73.

10. Frostegard J. Immunity, atherosclerosis and cardiovascular disease. BMC Med. 2013;11:117.

11. Crowther MA. Pathogenesis of atherosclerosis. Hematology Am Soc Hematol Educ Program. 2005;2005(1):436-41.

12. Huang RC, Burke V, Newnham JP, Stanley FJ, Kendall GE, Landau LI, Oddy WH, Blake KV, Palmer LJ, Beilin L. Perinatal and childhood origins of cardiovascular disease. Int J Obes. 2007;31(2):236-44.

13. Praveen PA, Roy A, Prabhakaran D. Cardiovascular disease risk factors: a childhood perspective. Indian J Pediatr. 2013;80(Suppl 1):S3-12.

14. Berenson GS, Srinivasan SR, Bao W, Newman WP 3rd, Tracy RE, Wattigney WA. Association between multiple cardiovascular risk factors and atherosclerosis in children and young adults. The Bogalusa Heart Study. N Engl J Med. 1998; 338(23):1650-6.

15. Goodman E, Dolan LM, Morrison JA, Daniels SR. Factor analysis of clustered cardiovascular risks in adolescence: obesity is the predominant correlate of risk among youth. Circulation. 2005;111(15):1970-7.

16. McGill HC Jr, McMahan CA, Herderick EE, Malcom GT, Tracy RE, Strong JP. Origin of atherosclerosis in childhood and adolescence. Am J Clin Nutr. 2000;72(5 Suppl):1307S-15S.

17. Chen X, Wang Y. Tracking of blood pressure from childhood to adulthood: a systematic review and meta-regression analysis. Circulation. 2008;117(25):3171-80.

18. Hong YM. Atherosclerotic cardiovascular disease beginning in childhood. Korean Circ J. 2010;40(1):1-9.
19. Cardiovascular disease in children and youth, Fact Sheets, World Heart Federation, http://www.world-heart-federation.org/press/fact-sheets/cvd-inchildren-and-youth/. Accessed 20 May 2016.

20. Falkner B. Hypertension in children and adolescents: epidemiology and natural history. Pediatr Nephrol. 2010;25(7):1219-24.

21. Vanhecke TE, Miller WM, Franklin BA, Weber JE, McCullough PA. Awareness, knowledge, and perception of heart disease among adolescents. Eur J Cardiovasc Prev Rehabil. 2006;13(5):718-23.

22. Prasad DS, Kabir Z, Dash AK, Das BC. Childhood cardiovascular risk factors in South Asians: A cause of concern for adult cardiovascular disease epidemic. Ann Pediatr Cardiol. 2011;4(2):166-71.

23. Gupta R, Misra A, Vikram NK, Kondal D, Gupta SS, Agrawal A, Pandey RM. Younger age of escalation of cardiovascular risk factors in Asian Indian subjects. BMC Cardiovasc Disord. 2009;9:28.

24. Misra A, Shah P, Goel K, Hazra DK, Gupta R, Seth P, Tallikoti P, Mohan I, Bhargava R, Bajaj $S$, et al. The high burden of obesity and abdominal obesity in urban Indian schoolchildren: a multicentric study of 38,296 children. Ann Nutr Metab. 2011;58(3):203-11.

25. Patil T, Patil S, Patil A. Evaluation of sustained blood pressure elevation in children. Indian Heart J. 2014;66(5):559.

26. Bennett S, Woods T, Liyanage WM, Smith DL. A simplified general method for cluster-sample surveys of health in developing countries. World Health Stat Q. 1991;44(3):98-106.

27. Cochran WG. Sampling techniques. Hoboken: John Wiley \& Sons; 2007.

28. Kish L, Groves RM, Krotki KP. Sampling errors for fertility surveys. 1976.

29. Deniz MS, Alsaffar AA. Assessing the validity and reliability of a questionnaire on dietary fibre-related knowledge in a Turkish student population. J Health Popul Nutr. 2013;31(4):497-503.

30. Omidvar S, Begum K. Dietary pattern, food habits and preferences among adolescents and adult student girls from urban area, South India. Indian J Fundam Appl Life Sci. 2014;4(2):465-73.

31. Kotecha PV, Patel SV, Baxi RK, Mazumdar VS, Shobha M, Mehta KG, Mansi D, Ekta M. Dietary pattern of schoolgoing adolescents in urban Baroda, India. J Health Popul Nutr. 2013;31(4):490-6.

32. Jaaskelainen A, Schwab U, Kolehmainen M, Pirkola J, Jarvelin MR, Laitinen J. Associations of meal frequency and breakfast with obesity and metabolic syndrome traits in adolescents of Northern Finland Birth Cohort 1986. Nutr Metab Cardiovasc Dis. 2013:23(10):1002-9.

33. Cahill L, Chiuve S, Mekary R. Skipping breakfast or eating late at night increases risk of coronary heart disease. Circulation. 2013;128(4):337-43.

34. Bo S, De Carli L, Venco E, Fanzola I, Maiandi M, De Michieli F, Durazzo M, Beccuti G, Cavallo-Perin P, Ghigo E, et al. Impact of snacking pattern on overweight and obesity risk in a cohort of 11- to 13-year-old adolescents. J Pediatr Gastroenterol Nutr. 2014;59(4):465-71.

35. Chen LJ, Haase AM, Fox KR. Physical activity among adolescents in Taiwan. Asia Pac J Clin Nutr. 2007;16(2):354-61.

36. Larsman $\mathrm{P}$, Eklof $\mathrm{M}$, Torner M. Adolescents, risk perceptions in relation to risk behavior with long-term health consequences; antecedents and outcomes: a literature review. Saf Sci. 2012:50(9):1740-8.

37. Falkner B, Daniels SR, Flynn JT, Gidding S, Green LA, Ingelfinger JR, Lauer RM, Morgenstern BZ, Portman RJ, Prineas RJ, et al. The fourth report on the diagnosis, evaluation, and treatment of high blood pressure in children and adolescents. Pediatrics. 2004;114(2 Suppl 4th Report):555-76.

38. Covelli MM. Efficacy of a school-based cardiac health promotion intervention program for African-American adolescents. Appl Nurs Res. 2008;21(4):173-80.

39. Harrell JS, McMurray RG, Bangdiwala SI, Frauman AC, Gansky SA, Bradley CB. Effects of a school-based intervention to reduce cardiovascular disease risk factors in elementary-school children: the Cardiovascular Health in Children (CHIC) study. J Pediatr. 1996;128(6):797-805.

40. Hollar D, Messiah SE, Lopez-Mitnik G, Hollar TL, Almon M, Agatston AS. Healthier options for public schoolchildren program improves weight and blood pressure in 6- to 13-year-olds. J Am Diet Assoc. 2010;110(2):261-7.

41. McMurray RG, Harrell JS, Bangdiwala SI, Bradley CB, Deng S, Levine A. A school-based intervention can reduce body fat and blood pressure in young adolescents. J Adolesc Health. 2002;31 (2):125-32.

42. Batlish R, Jadhav SL, Banerjee A. Coronary heart disease: awareness of risk factors and lifestyle among school-going adolescents. Indian J Med Sci. 2007:61(8):474-6.

43. George GM, Sharma KK, Ramakrishnan S, Gupta SK. A study of cardiovascular risk factors and its knowledge among school children of Delhi. Indian Heart J. 2014;66(3):263-71. 
44. Divakaran B, Muttapillymyalil J, Sreedharan J, Shalini K. Lifestyle riskfactors of noncommunicable diseases: awareness among school children. Indian J Cancer. 2010;47(Suppl 1):9-13.

45. Collins KM, Dantico M, Shearer NB, Mossman KL. Heart disease awareness among college students. J Community Health. 2004;29(5):405-20.

46. Yadav K, Wagle R. Knowledge and attitude regarding major risk factors of cardiovascular diseases among 15-19 year old students of Kathmandu District. Health Prospect. 2013;11:7-10.

47. Slovic P. Perception of risk. Science. 1987;236(4799):280-5

48. Meland E, Haugland S, Breidablik HJ. Body image and perceived health in adolescence. Health Educ Res. 2007;22(3):342-50.

49. Armstrong B, Westen SC, Janicke DM. The role of overweight perception and depressive symptoms in child and adolescent unhealthy weight control behaviors: a mediation model. J Pediatr Psychol. 2014;39(3):340-8.

50. Prajapati J, Oza J, Prajapati P, Bhagyalaxmi A, Rawal V. Prevalence of behavioural risk factors of cardiovascular diseases among school going adolescents of Ahmedabad, Gujarat. Health Popul Perspect Issues. 2009;32(4):198-203.

51. Allison KR, Adlaf EM, Dwyer JJ, Lysy DC, Irving HM. The decline in physical activity among adolescent students: a cross-national comparison. Can J Public Health. 2007:98(2):97-100.

52. Bachani D, Sogarwal R, Shukla S, Shelat T, Gupta S. Dietary Practices and Physical Activity Performed by Adolescent in Selected Districts of India. Indian J Community Health. 2013;25(2):171-7.

53. Dumith SC, Domingues MR, Gigante DP, Hallal PC, Menezes AM, Kohl HW. Prevalence and correlates of physical activity among adolescents from Southern Brazil. Rev Saude Publica. 2010;44(3):457-67.

54. Kjonniksen L, Torsheim T, Wold B. Tracking of leisure-time physical activity during adolescence and young adulthood: a 10-year longitudinal study. Int J Behav Nutr Phys Act. 2008;5:69.

55. Kimm SY, Glynn NW, Kriska AM, Barton BA, Kronsberg SS, Daniels SR, Crawford PB, Sabry ZI, Liu K. Decline in physical activity in black girls and white girls during adolescence. N Engl J Med. 2002;347(10):709-15.

56. Musaiger AO, Bader Z, Al-Roomi K, D'Souza R. Dietary and lifestyle habits amongst adolescents in Bahrain. Food Nutr Res. 2011:55:7122.

57. Samuelson G. Dietary habits and nutritional status in adolescents over Europe. An overview of current studies in the Nordic countries. Eur J Clin Nutr. 2000;54(Suppl 1):S21-8.

58. Li M, Dibley MJ, Sibbritt DW, Yan H. Dietary habits and overweight/obesity in adolescents in Xi'an City, China. Asia Pac J Clin Nutr. 2010;19(1):76-82.

59. Mota J, Fidalgo F, Silva R, Ribeiro JC, Santos R, Carvalho J, Santos MP. Relationships between physical activity, obesity and meal frequency in adolescents. Ann Hum Biol. 2008;35(1):1-10.

\section{Submit your next manuscript to BioMed Central and we will help you at every step:}

- We accept pre-submission inquiries

- Our selector tool helps you to find the most relevant journal

- We provide round the clock customer support

- Convenient online submission

- Thorough peer review

- Inclusion in PubMed and all major indexing services

- Maximum visibility for your research

Submit your manuscript at www.biomedcentral.com/submit

) Biomed Central 